\title{
Kebijakan Politik Turki Utsmani di Hijaz 1512-1566 M
}

\author{
Tati Rohayati ${ }^{1}$
}

\begin{abstract}
Abstrak
Studi ini menjawab satu pertanyaan yaitu bagaimana dampak kebijakan politik Turki Utsmani di Hijaz 1512-1566 M. Untuk menjawab pertanyaan tersebut digunakan metode historis, melalui sumber tertulis dengan pendekatan politik. Dikarenakan dari berbagai sumber tertulis masa pemerintahan Turki Utsmani (1512-1566 M), begitu kuat pengaruhnya terhadap negara-negara bercorak Islam yang ada di Timur Tengah, khususnya Hijaz. Akan tetapi dari berbagai studi ini, penulis belum menemukan keterangan atau penjelasan yang mendalam, pengaruh kebijakan Turki Utsmani itu begitu kuat. Temuan penulis bahwa kebijakan Turki Utsmani memberikan kemajuan yang signifikan terhadap Hijaz. Dalam hal politik, madzhab Sunni menjadi dominan di Timur Tengah, Hijaz menjadi sentral gerakan studi intelektual dengan menetapkan Syarîf di Makkah, Sançak di Jeddah, dan Muhafidz di Madinah. Gelar khalifah yang disandang Turki Utsmani menjadikan ia sebagai penguasa tunggal di Timur Tengah. Banyak negaranegara Islam meminta legitimasi gelar "kesultanan" kepada Sultan di Istanbul

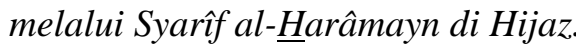

Kata Kunci: Hijaz, Kebijakan, Khalifah, Legitimasi, Turki Utsmani

\begin{abstract}
This study answered the question is how policy impacts the Ottoman Empire in 1512-1566 Hijaz. M. To answer these questions used the historical method, through written sources with a political approach. Due from various sources written during the reign of the Ottoman Empire (1512-1566 AD), so a strong influence on the character of Islam countries in the Middle East, especially the Hijaz. However, from various studies, the authors have not found profound information or explanations, the influence of the Ottoman policy was so strong. The findings of the authors that the policy of the Ottoman provide significant progress toward Hijaz. In terms of politics, Sunni sects became dominant in the Middle East, Hijaz became central to the movement of intellectual study to establish Sharif in Makkah, Sancak in Jeddah, and Muhafidz in Medina. Title that carried the Ottoman caliph make it as the sole ruler in the Middle East. Many Islamic countries ask legitimacy of the title of "the empire" to the Sultan in Istanbul with Sharif al-Haramayn in Hijaz. Keywords: Hijaz, Policy, Khalifah, Legitimacy, the Ottoman
\end{abstract}

\footnotetext{
${ }^{1}$ Penerima Beasiswa MORA KEMENAG
} 


\section{PENDAHULUAN}

Dari berbagai sumber tertulis ditemukan bahwa pada abad XVI masa pemerintahan Turki Utsmani (التركية عثمانيه) 1512-1566 M, begitu berpengaruh terhadap negara-negara bercorak Islam yang ada di Timur Tengah ${ }^{2}$ khususnya Hijaz (الحجاز). Akan tetapi dari berbagai studi itu, penulis belum menemukan keterangan atau penjelasan yang mendalam mengapa pengaruh (ekspansionisme) ${ }^{3}$ Kesultanan

${ }^{2}$ Definisi mengenai istilah Timur Tengah sesungguhnya masih belum jelas namun dari pakar sejarawan memberikan pengertian bahwa Timur Tengah itu wilayahnya terbentang dari lembah Sungai Nil (The Nile Valley) sampai negeri-negeri Muslim di Asia Tengah, dari Eropa yang paling Tenggara hingga Lautan Hindia. Dan sesungguhnya Amerika Serikat lah yang mempopulerkan istilah Timur Tengah setelah Perang Dunia II. Sejak lama Timur Tengah gencar dikenal sebagai persimpangan jalan dari apa yang disebut dengan Dunia Lama (Old World) atau Afro-Eurasia. Timur Tengah adalah wilayah yang secara politis dan budaya merupakan bagian dari benua Asia, atau AfrikaEurasia. Dimana pusat dari wilayah ini adalah daratan diantara Laut Mediterania dan Teluk Persia serta wilayah yang memanjang dari Anatolia, Jazirah Arab dan Semenanjung Sinai. Namun menurut PPB mengangap wilayah Timur Tengah adalah wilayah Asia Barat Daya (termasuk Siprus dan Iran) ditambah dengan Mesir. Secara sosial culture, Timur Tengah mencakup wilayah yang terdiri dari: Bahrain, Siprus, Mesir, Turki, Iran (Persia), Irak, Israel, Yordania, Kuwait, Lebanon, Oman, Qatar, Arab Saudi, Suriah, Uni Emirat Arab, Yaman dan Palestina. Namun dilihat secara geografi (peta) menunjukkan negara-negara yang diyakini sebagai bagian dari Timur Tengah adalah Arab Saudi, Yaman, Oman, Uni Emirat Arab, Bahrain, Qatar, Irak, Kuwait, lalu negara-negara Afrika Utara juga diikutsertakan: Maroko, Al-jazair, Libya, Tunisia, Mauritania, Sahara Barat, Sudan, Ethiopia, Eritrea, Djibouti, selain itu disertakan Iran, Pakistan dan Turki. Goldschmidt, Jr. Arthur, 1979. Concist History of The Middle East, The American University in Cairo Press. Dan Istadiyantha staf Fakultas Sastra dan Seni rupa Universitas Sebelas Maret Surakarta, "Permaslahan Istilah Timur Tengah".

${ }^{3}$ Ekspansionis menurut Kamus Besar Bahasa Indonesia (KBBI), adalah kecenderungan untuk memperluas daerah sendiri dengan memerangi dan menaklukkan negara-negara lain, terutama negaranegara tetangga yang berbatasan (negara,
Turki Utsmani itu begitu kuat. Timbul pertanyaan, bagaimana dampak kebijakan politik Turki Utsmani di Hijaz Tahun 15121566 M. Asumsi penulis bahwa kebijakan ${ }^{4}$ itu dilakukan dalam konteks kesultanan Turki Utsmani sebagai khalifah Islam. Kehadiran Turki Utsmani dengan kebijakannya memberikan kemajuan terhadap Hijaz.

Belajar dari pengalaman para sultan sebelumnya dan melihat situasi dan kondisi pemerintahannya, maka Turki Utsmani mengeluarkan beberapa kebijakan dalam rangka untuk membangun dan menjaga stabilitas pemerintahan dalam menghadapi berbagai tantangan yang ada. Bergeraknya pasukan Turki Utsmani ke wilayah Timur Tengah dalam rangka menyelamatkan dunia Islam secara umum dan wilayahwilayah Muslim secara khusus. $^{5}$

pemerintah, bangsa). Dendy Sugono, Kamus Bahasa Indonesia, (Pusat Bahasa: Departemen Pendidikan Nasional Jakarta, 2008). Selain itu, ekspansi adalah usaha yang dilakukan negara untuk meluaskan pengaruh atau wilayahnya, ekspansi dapat dilakukan melalui militer, politik atau ekonomi. Sedangkan ekspansionisme adalah politik atau tindakan melakukan ekspansi terutama ekspansi wilayah, oleh suatu bangsa terhadap wilayah negara lain. B.N. Marbun, Kamus Politik Ed.3 (Jakarta: Pustaka Sinar Harapan, 2007), cet.1.

${ }^{4}$ Kebijakan menurut Oxford English Dictionary yaitu sebagai: "Political sagacity; statecraft; prudent conduct; craftiness; course of action adopted by government, party, etc Jadi Kebijakan adalah seperangkat aksi atau rencana yang mengandung tujuan politik, atau usaha untuk mendefnisikan dan menyusun basis rasional untuk melakukan atau tidak melakukan suatu tindakan. Hogwood dan Gunn menyebutkan 10 penggunaan istilah kebijakan dalam pengertian modern sebagai label untuk sebuah bidang aktivitas, sebagai ekspresi tujuan umum atau aktivitas negara yang diharapkan, sebagai proposal spesifik, sebagai keputusan pemerintah, sebagai otorisasi formal, sebagai sebuah program, sebagai output, sebagai hasil (outcome), sebagai teori atau model, sebagai sebuah proses. (Wayne Parsons, Public Policy: Pengantar Teori dan Praktik Analisis kebijakan, (Jakarta: Kencana, 2008), cet.3 h.14-15.

${ }^{5}$ Tantangan Turki Utsmani 1512-1566 M yaitu datangnya kaum Salibis dari Spanyol melalui Laut Tengah, Orang-orang Portugis di lautan Hindia, Laut Arab, dan Laut Merah, adanya pemerintahan 
Hijaz menjadi tempat yang sangat penting baik secara praktis maupun simbolis. Kebijakan Turki Utsmani menjadikan Hijaz sebagai pusat indroktinasi dan legitimasi. Di mana dalam hal ini tidak bisa lepas dari peran khalifah, terutama menjaga keamanan jalur haji dan klaim akan gelar "khalifah" (خليفة). Hijaz menjadi kota yang luar biasa dengan dijadikannya sebagai pusat pemerintahan Turki Utsmani, bahkan Hijaz menjadi basis spiritual dan pusat dinamika intelektual. ${ }^{6}$

Penguasaan Hijaz sesungguhnya ditandai ketika Turki Utsmani mampu menaklukkan Mesir (مصر) pada $1517 \mathrm{M}^{7}$ sehingga gelar khalifah disandang oleh

Shafawi-Iran yang menyebarkan paham Syi'ah . Ali Muhammad Ash-Shalabi, Bangkit dan Runtuhnya Khilafah Utsmaniyah, (Jakarta: Pustaka Al-Kautsar, 2002), h. 214.

${ }^{6}$ Kemal H. Karpat, The Politicization of Islam: Reconstructing Identity, State, Faith, and Community in the Late Ottoman State, (New York: Oxford University Press, 2001).

${ }^{7}$ Istilah menaklukkan berasal dari kata "takluk" yang berarti daerah jajahan. Dalam Kamus Besar Bahasa Indonesia (KBBI) menaklukkan adalah menguasai, mengalahkan, menyerang, melawan, merebut suatu negeri, istilah menaklukkan disitu lebih mengarah pada menguasai sebuah negeri dengan cara perang. Dendy Sugono, Kamus Bahasa Indonesia (Jakarta: Pusat Bahasa Departemen Pendidikan Nasional, 2008), h. 34 dan h. 305. Ditandai masa pemerintahann Turki Utsmani menaklukkan Mesir dengan kekuatan militer, keunggulan strategi perang, alat-alat perang seperti meriam dan senapan. Dimana pasukan Turki Utsmani dan pasukan Mesir masa pemerintahan Tuman Bey bertemu di Gerbang Kairo pada 22 Januari 1517 M, perang tersebut dinamakan perang Al-Radaniyyah (الردنيّة) dengan kemenangan diraih oleh Turki Utsmani. Hassan Ibrahim Hassan, Sejarah dan Kebudayaan Islam, (Yogyakarta: Kota Kembang, 1968), h. 330-331. Adapun gambaran masa pemerintahan Turki Utsmani di Mesir yaitu: "Mesir kembali berada di bawah kekuasaan besar, sebagimana terjadi di awal masa-masa pemerintahan Islam. Tatkala Mesir berada sepenuhnya di tangan Selim I, dia mengampuni orang-orang Mamluk, mendistribusikan waqf, mengalokasikan dana untuk anak yatim, untuk benteng-benteng, dan mengalokasikan dana untuk orang-orang yang siap berperang, membebaskan cukai dan hutang. Ali Muhammad Ash-Shalabi, Bangkit dan Runtuhnya Khilafah Utsmaniyah, h. 228.
Turki Utsmani yang diambil dari al-

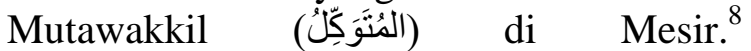
Bergeraknya pasukan Turki Utsmani ke Hijaz dalam rangka penegakan kekuasaan Turki Utsmani di Semenanjung Arabia (Bashrah, Mosul, Bahrain, Yaman, Oman, ${ }^{9}$ Ethiopia, Sudan, Somalia, Jibouti) dan kebanyakan Afrika Utara (Aljazair, Tunisia, Libya). Serta kebangkitan kembali perdagangan di Lautan Hindia. ${ }^{10}$

${ }^{8}$ Ali Mufrodi, Kerajaan Utsmani, (Jakarta: PT Ichtiar baru van Hoeve, 2002), h. 238. dan Ali Muhammad Ash-Shalabi, Bangkit dan Runtuhnya Khilafah Utsmaniyah memberikan keterangn bahwa berpindahnya pusat kekhalifahan terkait erat dengan penaklukan kesultanan Mamluk di Mesir. Kekhalifahan Bani Abbas di Kairo menyerahkan kekhalifahan kepada Sultan Selim I, yang kemudian dilanjutkan oleh anaknya yaitu Sŭleyman I. Paska terjadinya penguasaaan ini yaitu ketika ia mampu mengalahkan pemerintahan Shafawi di bagian Utara dan Barat Iran, maka Salim I mulai mengekspansi Mesir yang dilatarbelakangi karena Mesir (Mamluk) menunjukkan sikap permusuhan kepada Turki. Selim I memutuskan untuk perang melawan Mesir dengan melintasi gurun-gurun Palestina. Dan selama perjalanan menuju Mesir Selim I menangis dalam do'anya di masjid Shakhrah Al Quds (صخرة القد) Palestina. Memohon kepada Allah agar diberikan kemenangan. Untuk sekian kalinya Selim I pun berhasil menalukkan Mesir. Namun ada beberapa faktor yang turut mendukung keberhasilan ini diantaranya: keunggulan militer pasukan Utsmani, keunggulan strategi pasukan Utsmani, kokohnya mentalitas pasukan Utsmani, komitmen pasukan Utsmani untuk berpegang teguh pada Syari'ah Islam dan sejumlah pemimpin Mamluk memutuskan untuk bergabung kepada tentara Sultan Selim I. Ali Muhammad Ash-Shalabi, Bangkit dan Runtuhnya Khilafah Utsmaniyah (Jakarta: Pustaka Al-Kautsar, 2002), h. 226-227.

${ }^{9}$ Turki Utsmani di Oman membangun galangan kapal di Muskat pada 1542, dilakukan guna menghadapi Portugis yang bekerjasama dengan Shafawi di kota Bandar Abbas. Turki Utsmani menguasai Oman pada 1539. Calvin H. Allen Jr, Oman The Modernization Of The Sultanate, (Colorado: West Viewer Press, 1987), h. 34.

${ }^{10}$ Azyumardi Azra, Jaringan Ulama Timur Tengah dan Kepulauan Nusantara abad XVII dan XVII Akar Pembaharuan Islam di Indonesia, (Jakarta: Prenada Media, 2004), h. 64. Untuk keterangan lebih jelas mengenai penegakkan kekuasaan Turki Utsmani di Semenanjung Arabia dan Afrika Utara di bukunya Syafiq A. Mughni, Sejarah Kebudayaan Islam di Kawasan Turki, (Jakarta: Logos, 1997), h.76-86. 
Pada pemerintahan Turki utsmani 1512 $1566 \mathrm{M}$ ini, banyak pembangunan yang dilakukan di Hijaz, baik fisik maupun nonfisik, diantaranya pembangunan pelabuhan dagang dan pangkalan angkatan laut, masjid-masjid, jembatan, rumah sakit, sekolah, dan kota-kota besar yang berada di wilayah kekuasaannya. ${ }^{11}$ Pembangunan kota-kota itu, menjadikan bergantinya orientasi perekonomian Turki Utsmani dari agraris ${ }^{12}$ menuju perkotaan (terutama kotakota pesisir yang menjadi tumpuan perdagangan lautnya, menyebabkan beralihnya penduduk agraris menjadi kaum urban, ${ }^{13}$ yang mendorong timbulnya sektor industri, dengan didirikannya pabrik-pabrik yang memproduksi barang yang dibutuhkan.

Pembanguan non-fisik diantaranya, hukum-hukum dibuat sebagai peraturan resmi Kesultanan Turki Utsmani, juga mengembangkan keilmuan seperti filsafat, astronomi, navigasi dan kedokteran. ${ }^{14}$ Sebuah kebijakan keuangan Turki Utsmani yang berupa bantuan subsidi khusus bagi

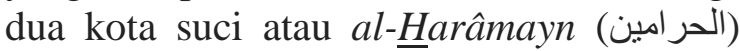
(Makkah مكّة dan Madinah المدينة (ادنة) dibebankan kepada gubernur Mesir.

${ }^{11}$ Lord Eversley's, The Turkish Empire, (Lahore: Syaikh Muhammad Ashraf Kashmiri Bazar, 1954), h. 61. Angkatan Laut Turki Utsmani berkekuatan 2000 kapal perang dengan 75.000 pelaut. angkatan laut ini berperan dominan dalam menghadapi Portugis dan untuk melebarkan sayap kekuasaanya, penguasa Turki Utsmani mempunyai kebijakan untuk angkatan lautnya di Lautan Hindia yaitu 25 armada kapal perang dengan 4000 orang.

${ }^{12}$ Hasil komoditi yang ada di wilayah Turki Utsmani, terutama di wilayah pedalaman adalah, gandum, beras, gula, buah-buahan, kayu, emas, besi, maupun industri tekstil. Adapun hasil peternakan berupa kambing, kuda, unta, ditambah dengan hasil laut. Andrew Heritage, The Time Atlas of Word History, (London: Time Books Limited, 1984), h. 179-180.

${ }^{13}$ Diperkirakan jumlah seluruh penduduk wilayah Turki Utsmani, kurang lebih berjumlah 14 juta jiwa. Kota Istanbul sendiri, berpenduduk kira-kira 200.000 jiwa pada pertengahan abad ke-16. Heritage, The Time Atlas, h. 170.

${ }^{14}$ Karen Amstrong, Islam Sejarah Singkat, terj. Fungky K.T, (Yogyakarta: Penerbit Jendela, 2005), h. 154 .
Mereka mendapat perhatian khusus, dengan memberi mereka tiga macam bantuan berupa: Ta'yinat (الَتْيْنَاتِ), Waq(الوقف) dan Surre, untuk dibagikan kepada seluruh penduduk dua kota tersebut, yang jumlahnya terus bertambah. ${ }^{15}$

\section{PEMBAHASAN}

\section{A. Turki Utsmani di Hijaz}

Berawal dari kemenangan melawan Shafawi, maka Selim I tergerak untuk menaklukkan Mamluk dikarenakan ternyata ada intrik dari Sultan Al-Ghawri yang tengah beralinasi dengan Shafawi. Selim I siap berperang dengan Mamluk yang saat itu mengalami kemunduran akibat takluknya angkatan laut mereka oleh pasukan Portugis, hal itu mengakibatkan hancurnya perekonomian Mamluk dikarenakan jalur perdagangan laut dikuasai Portugis. Selim I menyadari bahwa peluang menaklukkan Mamluk lebih mudah, apalagi rakyat sudah tidak kuat lagi dengan keadaan ekonomi, dan rakyat banyak yang bersiap untuk mendukung Turki Utsmani. ${ }^{16}$

Pada Agustus 1516 M, Selim I memutuskan untuk perang dan membawa pasukannya melalui Anatolia. Kedua pasukan bertemu di Marj Dabiq, peperangan ini dengan mudah dimenangkan oleh pasukan Sultan Selim I dengan didukung oleh keunggulan

${ }^{15}$ Ta'yinat (الَتِْْيْنَاتِ) yaitu bantuan keuangan untuk pembelian makanan dan kebutuhan bagi keluarga Syarîf al-Harâmayn, para Sayyid, dan para ulama setiap tahun. Waqf (الوقف) merupakan sebuah lembaga keuangan yang mengurus para jama'ah haji, yang dipimpin oleh Amir al-hajj, yang memberikan bantuan keuangan untuk menutupi biaya kafilah haji yang meninggalkan Mesir setiap tahunnya, Surre: berarti "dompet", merupakan bantuan keuangan berupa uang tunai untuk pegawai rendah, ulama dan penduduk di al- $\underline{H}$ arâmayn setiap tahun. Azyumardi Azra, Jaringan Ulama Timur Tengah dan Kepulauan Nusantara, h. 64.

${ }^{16}$ Sobari, Kebijakan Pemerintah Sultan Sulaiman I (918-926/1512-1520 M), (Skripsi S1 Fakultas Adab dan Budaya, Universitas Islam Negeri Sunan Kalijaga Yogyakarta, 2009), h. 58. 
teknologi meriam dan senapan. Sultan Mamluk Qanswh al-Ghawri pun terbunuh dalam peperangan itu. ${ }^{17}$ Setelah menang dari Mamluk, Selim I mengangkat petinggi Mamluk bernama Tuman Bey sebagai gubernur wilayah Mesir dan Suriah. Namun karena ketamakannya Tuman Bey tidak puas dengan jabatannya, bahkan ia mendeklarasikan diri sebagai sultan Dinasti Mamluk. Secara otomatis Selim I tidak terima dan menyatakan perang dengannya. Selim I segera membawa pasukan menyebrangi Gurun Sinai dan masuk ke Mesir. Peperangan pun dimulai dengan pemerintahan Mamluk yang baru yaitu Tuman Bey yang dikenal dengan perang “Al-Radaniyyah" (الردنيّة). Perang ini terjadi di gerbang kota Kairo pada tahun 1517 M. ${ }^{18}$

Dengan didukung oleh meriam dan senapan maka Turki Utsmani menang dalam perang ini. Setelah kemenangan ini Selim I tidak berhenti begitu saja, ia pun harus menghadapi pemberontakan di Ibukota kerajaannya yaitu Kairo. Tercatat bahwa setelah tiga hari peperangan korban tewas mencapai 3.000-an penduduk, Tuman Bey tewas dan digantung digerbang Kairo. Akhirnya kairo pun takluk ditangan Selim I. ${ }^{19}$

Maka dari itu, Setelah Turki Utsmani mengalahkan Mamluk, secara otomatis Mesir dan Hijaz pun berada dalam penguasaanya, sebagaimana disebutkan bahwa bagi siapa saja yang mampu menguasai Mesir ia berkewajiban untuk melindungi Hijaz. Hal ini disebabkan karena Hijaz letaknya cukup strategis bagi Mesir untuk kepentingan pertahanan dan penyerbuan keluar. Mesir menjadi pusat

\footnotetext{
${ }^{17}$ Suraiya Faroqhi, Pilgrims and Sultans The Hajj Under The Ottoman 1517-1683 M, (London: I.B. Tauris \& Co.Lt, 1994), h. 147-147.

${ }^{18}$ Hassan Ibrahim Hassan, Sejarah dan Kebudayaan Islam, (Yogyakarta: Kota Kembang, 1968), h. 330331.

${ }^{19}$ Hassan, Sejarah dan Kebudayaan Islam, h. 331.
}

kafilah-kafilah haji dari seluruh Afrika yang harus dijamin keselamatannya. ${ }^{20}$

Seperti kita ketahui bahwa sebelum jatuhnya Dinasti Mamluk ke tangan Turki Utsmani, Hijaz masih di bawah pemerintahannya, namun dengan keberhasilan Sultan Selim I menaklukkan Mesir pada $1517 \mathrm{M}$ dan menangkap AlMutawakkil III khalifah terakhir dari Abbasiyah yang tinggal di sana. ${ }^{21}$ Penjaga wilayah Suci kota Makkah dan Madinah yang saat itu dipimpin oleh Barakat II Ibn Muhammad menghadap kepadanya dan menyatakan tunduk kepada kekuasaan kerajaan Turki Utsmani, ia menggantungkan pemerintahan dan semua keputusan politik kepada Turki Utsmani. Kemudian Barakat II Ibn Muhammad menyerahkan simbol-simbol suci Nabi Muhammad SAW dan kunci-kunci Ka'bah. $^{22}$ Dan dengan itu Selim I mengangkat Barakat II Ibn Muhammad menjadi penguasa Hijaz dan Makkah. Sultan Selim I telah menjadi penjaga dua Kota Suci menjadikan semakin kuat posisinya dimata kaum muslimin. ${ }^{23}$ Setelah penaklukkan Mesir tersebut, Sultan Selim I

${ }^{20}$ Badri Yatim, Perubahan Sosial Politik di Hijaz 1800 s/d 1925 dan Pengaruhnya terhadap lembaga dan kehidupan Keagamaan; Perspektif Sejarah Sosial, dalam bukunya Sejarah Sosial Keagamaan Tanah Suci; Makkah dan Madinah 1800-1925. (Jakarta: Logos Wacana Ilmu, 1999), h. 56.

${ }^{21}$ Sobari, Kebijakan Pemerintah Sultan Sulaiman I, h. 47.

${ }^{22}$ Sebagai khalifah Islam terakhir, para sultan Utsmani berhak menjaga warisan Nabi (Dzakha'ir Nabawiyyah) (الذخائر النبوية), yang pada 1517 di bawa oleh Sultan Selim I ke Konstantinopel setelah menaklukkan Mesir, sejak itu relic (meliputi jubah Nabi, stempel, parabotan, sepatu, gigi, dan rambut Nabi Muhammad SAW) tersebut disimpan diruangan khusus dalam sebuah istana yang dijaga ketat dan dipandang sebagai simbol keagungan. Philip K. Hitti, History of the Arabs, edisi revisi dari History of the Arabs; From the Earliest Times to the Present, ed. 10, Penerj. R. Cecep Lukman dan Dedi Slamet Riyadi, (New York: Palgrave Macmillan Press, 2002), h. 232.

${ }^{23}$ Ali Muhammad Ash-Shalabi, Bangkit dan Runtuhnya Khilafah Utsmaniyah I, (Jakarta: Al Husna Zikra, 1997), h. 230. 
mengklaim dirinya sebagai khalifah Islam, dilihat secara de facto dan de jure, telah berhak menggunakan gelar tersebut dikarenakan Makkah dan Madinah sudah di bawah penguasaannya. ${ }^{24}$

Peristiwa masuknya Hijaz kedalam pemerintahan Turki Utsmani, memberikan pengaruh semakin meluasnya wilayah pemerintahan Turki Utsmani di Laut Merah, dan bisa mencegah ancaman Portugis atas Hijaz. Selim I mengambil langkah-langkah khusus untuk menjamin keamanan bagi perjalanan haji, maka dari itu seluruh rute perjalanan haji diwilayah kekuasaan Turki Utsmani ditempatkan dibawah kontrolnya. Seluruh kafilah haji diorganisir di bawah pengawasan sultansultan Utsmani, sehingga para jama'ah yang datang dari negeri-negeri Timur, dilindungi perjalanannya dari serangan dan gangguan Portugis. Dengan pengamanan itu, kini jama'ah haji langsung dapat menuju ke Makkah tanpa hambatan atau rasa takut untuk menghadapi rintangan.

Turki Utsmani melepas armada yang tangguh dibawah komando Khadim Sulayman Pasya, dengan tujuan untuk membebaskan semua pelabuhan yang dikuasai Portugis. ${ }^{25}$ Dengan menciptakan keamanan dan ketertiban bagi perjalanan haji ini, Turki Utsmani memberikan akomodasi perjalanan-perjalanan haji, pendapatan haji itu kemudian diolah untuk kepentingan Makkah dan Madinah. $^{26}$ Setelah peristiwa ini, maka Turki Utsmani berkewajiban untuk melindungi Hijaz dikarenakan sudah masuk dalam wilayah penguasaannya dan mengetahui arti tanggung jawab mempertahankan tempattempat suci kaum muslim.

Selim I wafat pada 9 Syawal $926 \mathrm{H} /$ $1520 \mathrm{M}$, maka kepemimpinan digantikan

\footnotetext{
${ }^{24}$ Philip K. Hitti, History Of The Arabs, h. 231 dan h. 901.

${ }^{25}$ Suraiya Paroqhi, Pilgrims and Sultants, The Hajj Under The Ottoman 1517-1683. (London: I.B. Tauris \& Co.Lt, 1994), h. 33.

${ }^{26}$ Azyumardi Azra, Jaringan Ulama Timur Tengah, h. 38.
}

oleh anaknya, Sŭleyman $\mathrm{I}^{27}$ yang diberikan

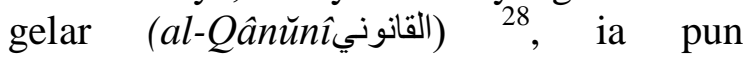
meneruskan perjuangan ayahnya untuk memberikan pengamanan terhadap jalur haji yang ada di Lautan Hindia. ${ }^{29}$ Ia melebarkan sayap kekuasaannya dengan merekrut angkatan lautnya untuk lebih dominan dalam menghadapi Portugis. Penguasa Turki Utsmani mempunyai kebijakan untuk angkatan lautnya di Lautan Hindia, yang hanya menyediakan 25 armada kapal perang dengan 4000 orang pelaut saja. $^{30}$

Dengan beberapa peristiwa tersebut, kita bisa melihat bagaimana proses masuknya Hijaz ke dalam kekuasaan Turki Utsmani, sebuah perjalanan yang amat panjang. Selanjutnya setelah masuknya Hijaz kedalam kekuasaan Turki Utsmani, maka Turki Utsmani menetapkan beberapa kebijakan dalam menjalankan pemerintahannya. Berikut dijelaskan beberapa kebijakan yang diterapkan.

\section{B. Kebijakan Turki Utsmani di Hijaz}

Keberhasilan Selim I dalam menguasai Hijaz, menjadikan Turki Utsmani pada puncak kejayaan. Sebuah kebijakan yang akan dikeluarkan tidak semena-mena dikeluarkan tanpa alasan apapun,

\footnotetext{
${ }^{27}$ Jika kita melihat silsilah sultan yang memerintah Turki Utsmani, terlihat Sulaiman I merupakan anak dari Selim I yang sudah dipersiapkan untuk menggantikan posisi kepemimpinannya kelak. Silsilah bisa dilihat di lampiran. Ali Mufrodi, Kerajaan Utsmani, (Jakarta: PT Ichtiar baru van Hoeve, 2002), Cet. 1 h. 245.

${ }^{28}$ Pemberian gelar Al-Qanuni ini berawal dari masa pemerintahannya yang memulai program dalam mereformasi pengadilan (pembuat hukum), reformasi ini mengakhiri aturan ksatria arbitrer yang dijalankan pendahulunya dan menciptakan sebuah sistem hukum baru yang melindungi kehidupan, property dan hak sipil rakyatnya. John Freely, Istanbul Kota Kekaisaran, penerj. Fahmy Yamani, (Jakarta: Pustaka Alfabet, 2012), Cet. I h. 246.

${ }^{29}$ Smith Michael Llewellyn, The Fall of Constantinopl in History Makers magazine No. 5, (London, Marshall Cavendish, Sidgwick \& Jackson, 1969), h. 189.

${ }^{30}$ Ira M Lapidus, Sejarah Sosial Umat Islam, h. 480.
} 
melainkan ada alasan mengapa sebuah kebijakan itu dikeluarkan. ${ }^{31}$

Setiap pemimpin mempunyai tanggung jawab untuk mempertahankan wilayahnya, menegakkan keadilan, mengangkat para pejabat negara, menarik pajak, mengatur dana masyarakat, menghukum orang yang melanggar hukum, dan lain sebagainya, setidaknya itulah beberapa peran dari khalifah (خليفة). ${ }^{32}$ Dalam menjalankan roda pemerintahan, seorang pemimpin dianggap perlu mengeluarkan kebijakan sesuai dengan kondisi dan kebutuhan dari pemerintah.

Kebijakan Turki Utsmani dilatarbelakangi oleh dua faktor yaitu faktor internal dan faktor eksternal. Adapun untuk faktor internal yaitu; adanya perasaan puas ketika Turki Utsmani mampu mencapai ekspansi ke Eropa (Emperium Power). ${ }^{33}$ Turki Utsmani sebagai pengusung Ortodoksi Sunni berkewajiban untuk melindungi dunia Islam Sunni dari ancaman Syi'ah. ${ }^{34}$ Faktor eksternal yaitu adanya tantangan dan ancaman dari pihak luar, seperti datangnya Portugis di Lautan Hindia. ${ }^{35}$

\footnotetext{
${ }^{31}$ Sobari, Kebijakan Pemerintah Sultan Sulaiman, h. 51.

${ }^{32}$ Philip K. Hitti, History Of The Arabs, h. 231.

${ }^{33}$ Jika kita melihat perjalanan sejarahnya, terlihat keberhasilan itu puncaknya masa Sultan Muhamad Al-Fatih (محمد الفا تح), kemudian Bayazid II yang mampu menaklukkan Eropa dan merangkul negerinegeri dalam penguasaannya.

${ }^{34}$ Ali Muhammad Ash-Shalabi, Bangkit dan Runtuhnya Khilafah Utsmaniyah, h. 214.

${ }^{35}$ Merujuk pada teori Ibn Khaldun mengenai berdirinya sebuah negara (ashabiyah) bahwa; agama mempunyai peranan penting dalam pembentuk persatuan. Semangat persatuan rakyat yang dibentuk melalui peran agama, tidak bisa ditandingi oleh semangat persatuan yang dibentuk oleh faktor lainnya. Ashabiyah sangat menentukan kemenangan dan keberlangsungan hidup suatu negara, dinasti ataupun kerajaan. Jika unsur ashabiyah suatu negara sudah melemah maka negara itu berada dalam ancaman keruntuhan. Oleh karena itu teori ashabiyah ini tidak bisa disangkal keberadaannya. Ibn Khaldun, Muqaddimah, terj. Ahmadie Thoha, (Jakarta: Pustaka Firdaus, 2001).
}

Ambisi penguasaan Turki Utsmani di Timur Tengah membawa Turki Utsmani menjadi khalifah Islam yang kuat pada masanya, sehingga berkewajiban untuk menyelamatkan dunia Islam secara umum dan wilayah-wilayah Muslim secara khusus. Setelah berhasil menjadi penguasa, dikeluarkanlah kebijakan Turki Utsmani pada 1512-1577 $\mathrm{M}$ dalam rangka untuk membangun dan menjaga stabilitas pemerintahan dalam menghadapi berbagai tantangan yang ada pada masa pemerintahannnya ${ }^{36}$.

Di bawah ini ada beberapa kebijakan yang dikeluarkan oleh Turki Utsmani menyangkut beberapa bidang diantaranya;

\section{Politik}

Seperti dalam pembahasan Hijaz di bawah kekuasaan Turki Utsmani, bahwa setelah Selim I berhasil menaklukkan Mesir, para penguasa Hijaz menaruh kepercayaan kepada Turki Utsmani sebagai pewaris khalifah Islam, dan dipandang sebagai penjaga agama melawan orang kafir. Dengan tunduknya Mesir ini, tidak ada pilihan lain lagi bagi syarîf Makkah, kecuali tunduk pula kepada penguasa Turki Utsmani. Dan ketika Selim I masih berada di Mesir, ia menerima Abu Numai putera syarîf Makkah, Barakat II Ibn Muhammad datang untuk menyatakan tunduk dari ayahnya kepada Turki Utsmani. Sejak pernyataan tunduk tersebut, para penguasa Turki Utsmani mulai menjalin diplomasi dengan Hijaz.

Dengan diplomasi ini, para penguasa Turki Utsmani memberikan perhatian lebih terhadap Hijaz dan sekitarnya yang ditetapkan sebagai tempat suci. Sebagai pemimpin baru, Turki Utsmani berusaha

\footnotetext{
${ }^{36}$ Tantangan Turki Utsmani 1512-1566 M yaitu datangnya kaum Salibis dari Spanyol melalui Laut Tengah, Orang-orang Portugis di lautan Hindia, Laut Arab, dan Laut Merah, adanya pemerintahan Shafawi-Iran yang menyebarkan paham Syi'ah, melindungi Makah dan Madinah. Ali Muhammad Ash-Shalabi, Bangkit dan Runtuhnya Khilafah Utsmaniyah, (Jakarta: Pustaka Al-Kautsar, 2002), h. 214.
} 
untuk melindungi jama'ah haji yang mencakup jiwa dan harta mereka. Oleh karena itu Turki Utsmani memfasilitasi mereka yang hendak menunaikan ibadah haji dengan membentuk kafilah-kafilah haji, memperbaiki jalan raya, membangun benteng, menggali sumur disepanjang rute haji, mendirikan penginapan dan pos penjagaan. $^{37}$

Ada beberapa rute perjalanan haji serta pelabuhan dagang masa Turki Utsmani yaitu;

\section{a) Lintas Darat}

Pertama, rute dari Kairo (القا هر ة), (dari Kairo menuju Bilbays terus ke Nakhl kemudian di 'Aqaba, Al-Muwaylih, Qal'at al-'Azlam, Al-Wajh (الوجه), Yanbu', Badr Hŭnayn, memasuki kawasan Madinah kemudian ke Mastŭrah, Râbigh, AlQadîmah (القديمة), 'Usfần, Jeddah, Makkah dan Mina). Kedua, rute dari Istanbul, (dari Istanbul menuju Üskŭdar, Izmit, Eskişehir, Akşehir, Konya, Adana, Antakya, Aleppo, Hamâh, Hims, Damaskus yang bersebelahan dengan Laut Mediterania, AlMafrak, Az-zarqâ, melewati Laut Mati, menuju Al-Qatrânah, 'Unayzah, Ma'ân, kemudian ke Tabŭk, Al-'Ulâ, menuju Madinah, Mekkah dan Mina yang berbatasan dengan Laut Merah). Adapun rute kurier penguasaan Turki Utsmani yaitu dari Istanbul, Üskŭdar, Tosya, Merzifon, Amasya, Tokat, Sivas, Malatya, Bayburt, Erzurum, Diyârbakr, Mardin, Mosul, melintasi sungai Tigris, Baghdad, dan Bashrah. $^{38}$

Ketiga, rute jalur Eropa yaitu dari Istanbul (Konstantinopel)-Kiev-Moskow, kemudian bisa juga melalui VeneziaBudapest-Wina, atau melalui Athena-

\footnotetext{
${ }^{37}$ http://www.jurnalhaji.com/pernik-haji/haji-padamasadaulahutsmaniyah/\#sthash. WBD2N6at. dpuf Akses: 30 Januari 2014, pukul: 09.28 WIB.

${ }^{38}$ Suraiya Paroqhi, Pilgrams and Sultans, The Hajj Under The Ottoman 1517-1683 M, (London: I.B. Tauris \& Co.Lt, 1994).
}

Budapest dan Wina. $^{39}$ Perlu diketahui bahwa Athena-Wina via Istanbul-Wina merupakan kota pusat perdagangan muslim utama di Balkan. Turki Utsmani berambisi menguasai jalur ini dikarenakan jalur ini merupakan jalur utama jaringan perdagangan, seperti: Bukarest, Beograd, Sofia dan Athena. ${ }^{40}$

Keempat, rute jalur Asia yaitu dari Atlantik-Samudera Hindia via tanjung Harapan ke Asia Tenggara, melalui jalur perdagangan darat via Yaman dan Hijaz. Rute yang lebih cepat Dapat ditempuh melalui Teluk Persia di Timur melalui Bashrah atau Bahrain-baghdad-AleppoBursa, ataupun dari Tabriz di Persia Utara, akan tetapi rute ini berbahaya karena ada aliansi Shafawi-Portugis yang menguasai bagian timur Persia. ${ }^{41}$ Rute bagian barat lebih aman yaitu dari Aden, Sana'a atau Jeddah-Madinah-Tripoli-Damaskus-

Aleppo-Bursa ataupun melalui Kairo dan Suez-Tripoli-Damaskus-Aleppo-Bursa.

Bursa di Anatolia merupakan pusat dristibusi dan perdagangan barang terbesar di Asia. Kota ini berda di jalur penting dari Asia sebelum menuju Eropa dari Damaskus, Tripoli dan Aleppo di Selatan (provinsi-provinsi Syam). ${ }^{42}$

Kelima, jalur Afrika. Untuk jalur Afrika sendiri tidak begitu baik, dikarenakan bagi Turki Utsmani hanya sebagai benteng militer dan jalur perdagangan saja, jalan yang membentang di sepanjang Afrika Utara mulai dari Mesir hingga kota-kota di Maghrib. Kairo dan al-jirs memegang penting jalur darat di Afrika Utara. Kedua kota ini berfungsi sebagai pusat distribusi barang dan perdagangan, baik ke wilayah Yunani dan Italia melalui Tripoli-Palermo

${ }^{39}$ Richard J Russel dan Fred B. Kniffen, Culture World, (New York: Glorier Incorporated, 1961), h. 160 yang di kutip oleh Reyhan Biadillah, "Kebijakan Ekonomi Turki Utsmani 1514-1574.

${ }^{40}$ H. T Noris, Islam In The Balkans Religion And Society Between Europe And The Arab World, (South Carolina: University Of South Carolina Press, 1993), h. 53-54.

${ }^{41}$ Ira M. Lapidus, Sejarah Sosial Umat Islam, h. 480.

${ }^{42}$ Ira M. Lapidus, Sejarah Sosial Umat Islam, 507. 
di pulau Sisilia dan langsung ke Genoa dan Venezia lewat laut, maupun kota-kota di daerah Maghrib melalui Tlemcen dan Fez. Kembalinya jalur perdagangan dan distribusi di Hijaz dan Mesir, menghidupkan kembali jalur di Afrika Utara bagian timur dan tengah. ${ }^{43}$

\section{b) Lintas Laut}

Pertama, Laut Tengah merupakan jalur yang paling penting sebelum di jelajahinya Samudera Atlantik yang menghubungkan Asia dan Eropa. Untuk pelabuhan aliran dagang dari Asia ke Eropa disalurkan melalui Laut mediterania (Laut Tengah) melalui Mesir dan kota-kota pelabuhan disepanjang daerah Bulan Sabit Subur. ${ }^{44}$ Turki Utsmani mengamankan jalur disekitar Laut Aegean, dengan menguasai pulau Cofru, pulau Rhodes, pulau Siprus dan pulau-pulau disekitar Mediterania Timur.

Kedua, Laut Hitam pada abad XVI dikuasai oleh Turki Utsmani, keberadaan jalur perdagangan di Laut Hitam tidak begitu besar seperti Laut Tengah kecuali di Istanbul sebagai pusatnya dan kota-kota lain seperti Bursa. Di sekitar pintu masuk Laut Hitam dari arah barat ini, barangbarang dibawa menuju Krimea, ukraina, Polandia dan Rusia.

Ketiga, Laut Merah, Laut arab dan Teluk Persia (Samudera Hindia). Akses perdagangan di Laut Merah dan Samudera Hindia dicapai dari kota-kota pelabuhan yang tersebar di sekitar Laut Merah, baik di Hijaz maupun di Afrika Timur. Persaingan antara Turki Utsmani, Portugis dan Aceh di Samudera Hindia membuat banyak pihak berkepentingan untuk mendominasi Samudera Hindia. Gangguan Portugis menyebabkan tersendatnya jalur perdagangan dari Timur. Kapal-kapal dagang yang berlayar ke arah Barat,

\footnotetext{
${ }^{43}$ Ira M. Lapidus, Sejarah Sosial Umat Islam, 506.

${ }^{44}$ Reyhan Biadillah, Reyhan Biadillah, Kebijakan Ekonomi Turki Utsmani 1514-1574 M. (Skripsi S1 Fakultas Adab dan Ilmu Budaya, Universitas Islam Negeri Sunan Kalijaga Yogyakarta, 2010), h. 83.
}

dihabisi oleh Portugis yang berpangkalan di Malaka, Goa dan Kalikut, sebelum sempat berlabuh di Sana'a maupun Jeddah. Jalur perdagangan dilaut ini dipenuhi kapal-kapal yang berlayar dari Aceh, Cirebon dan Banten melalui Gujarat dan maladewa, atau langsung dari kota-kota pelabuhan yang tersebar di Asia Tenggara kecuali Malaka, menuju ke Maladewa atau ke Gujarat, sampai ke Timur Tengah (Aden). ${ }^{45}$

Pedagang dari Aceh hanya sebanyak lima kapal pertahun yang dapat berlabuh di Jeddah. Hal ini terjadi karena ada serangan Portugis di Samudera Hindia. Untuk pedagang-pedagang Cirebon dan Banten kapal-kapal melalui rute pesisir barat Sumatera guna menghindari Portugis untuk sampai ke Maladewa dan Timur Tengah. ${ }^{46}$ Jama'ah haji yang berasal dari Nusantara pergi haji sebelum adanya kapal api, tentu saja menggunakan perahu layar, yang sangat tergantung kepada musim. Dan biasanya para haji menumpang pada kapal dagang, perjalanan membawa mereka melalui beberapa pelabuhan di Nusantara ke Aceh, pelabuhan terakhir di Indonesia di mana mereka menunggu kapal ke India. Di India kemudian mereka mencari kapal yang bisa membawa mereka ke Hadramaut, Yaman atau langsung ke Jeddah. ${ }^{47}$

Kemudian pada periode selanjutnya (abad XVII-XVIII), jama'ah haji berangkat menggunakan Kapal Niaga domestik atau kapal niaga asing, meskipun pada abad XVI kapal niaga telah berkurang, namun masih dijumpai beberapa kapal niaga milik orang-orang Arab, Persia, Turki dan India yang beroperasi di Nusantara. Kapal itu melayari melalui jalur perdagangan Samudera India sampai ke jazirah Arab.

\footnotetext{
${ }^{45}$ D. J. M. Tate, The Making of Modern South East Asia Vol. 1 The European Conquest, (Kuala Lumpur: Oxford University Press, 1971), h. 45 yang dikutip oleh Reyhan Biadilla, Kebijakan Ekonomi Turki Utsmani 1514-1574, h. 86.

${ }^{46}$ Azyumardi Azra, Jaringan Ulama Timur Tengah, h. 40-41.

${ }^{47}$ Martin van Bruinessen, Kitab Kuning Pesantren dan Tarekat, h. 48.
} 
Melalui kapal itulah jama'ah haji berangkat ke Tanah Suci dan kembali ke Nusantara. ${ }^{48}$

Penguasaan atas Hijaz dan pengakuan gelar khalifah, memberikan pengaruh yang besar di bidang politik, dikarenakan banyak kesultanan muslim yang ada kala itu, mengakui bahwa Turki utsmani merupakan pemimpin dan pelindung Islam, dan meminta legitimasi gelar kesultanan kepadanya. Dengan begitu hubungan diplomatik pun dibangun dalam rangka membangun solideritas keislaman dikarenakan pada saat itu dunia Islam sedang dihadapkan dengan serangan Portugis yang beroperasi di Lautan Hindia. $^{49}$

\section{Pemerintahan}

Dalam sistem pemerintahan ini, Turki Utsmani menetapkan di Mesir dengan memperkuat tentara Jenissari dan menempatkan beberapa komandan militer dan gubernur, dimaksud agar dapat mensentralisasi kekuasaan yang memastikan kesinambungan dalam pengumpulan pajak untuk pemenuhan perbendaharaan Istanbul. Sedang untuk administrasi sendiri, difungsikan untuk menaklukkan seluruh negeri, menjaga kelangsungan pertanian, perairan, perdagangan dan terutama mengendalikan suku Badui.

Pada periode setengah abad pertama di Mesir, Turki Utsmani berusaha untuk memperbaiki irigasi, meningkatkan hasil pertanian, dan merombak perdagangan dengan membuka jalur India dan Mesir. Hal ini dirasa bagi Turki Utsmani memiliki posisi geopolitik yang penting bagi pengendalian wilayah Laut Merah, tempat suci jazirah Arab, Yaman, Nubia, dan Abessinia. $^{50}$

\footnotetext{
${ }^{48}$ M. Shaleh Putuhena, Historiografi Haji Indonesia, (Yogyakarta: PT LKiS Pelangi Aksara Yogyakarta, 2007), h. 131.

${ }^{49}$ Reyhan Biadillah, Kebijakan Ekonomi Turki Utsmani 1514-1574, h. 21.

${ }^{50}$ Syafiq A. Mughni, Sejarah Kebudayaan Islam di Kawasan Turki. (Jakarta: Logos, 1997), h. 76.
}

Untuk infrastuktur di Mesir sendiri, kesultanan Mamluk secara militer posisinya yang terpenting. Untuk institusi keagamaan di Mesir, Turki Utsmani mengorganisir lebih maju dengan mengangkat seorang qâdhî (قاضي) utama, sedangkan lembaga keagamaan lainnya diserahkan kepada ulama lokal dengan pengelompokkan berdasarkan madzhab masing-masing. Pengelompokkan itu dipimpin dibawah seorang Syaikh al-Azhar.

Bidang sosial politik, ulama dan sufi memegang peranan penting. Berawal dari periode Mamluk yang merupakan kekuatan perantara antar elit politik dengan rakyat biasa, disisi lain juga peran ulama dan sufi ini sebagai klien para elit politik kerajaan, yang memberikan mereka gaji, hadiah dan hak untuk mengelola waqf dan gaji atas pengajarannya. Selain itu pula, ulama dan sufi pun menjalin hubungan harmonis dengan masyarakat. Namun setelah beberapa periode berjalan hubungan antara Turki Utsmani dan Mamluk mulai berubah, kekuasaan politik gubernur provinsi mulai redup, para Mamluk memperoleh keuntungan dengan mengontrol atas biaya militer, pajak, kendali waqf ada ditangan mereka sehingga semuanya itu menjadi hak mereka seumur hidup. ${ }^{51}$

Namun di Hijaz, rupanya Sultan Selim I menyusun tata pemerintahan yang berbeda dibanding dengan negeri hasil taklukkannya yang lain. Perbedaan ini teletak pada kebijakan Sultan yang tetap mempertahankan posisi syarîf Makkah (nizzam al-asyrâf) (النظام kebijakan ini sesungguhnya meneruskan tradisi Dinasti Mamluk yang menguasai Hijaz sebelumnya.

\footnotetext{
${ }^{51}$ Mughni, Sejarah Kebudayaan Islam di Kawasan Turki, h. 76-78.

${ }^{52}$ Pemberlakuan syarîf (nizam al-asyrâf) di Makkah ini bermula dari kebijakan yang berhasil mendirikan pemerintahan yang dipimpin oleh Ja'far Ibn Muhammad Dinasti Iksidiyah dengan menurunkan para syarîf yang menggantikan para penguasa Makkah dan menggantikan posisi pemerintahan Bani Iksidiyah. Badri Yatim, Perubahan Sosial Politik di Hijaz, h. 32.
} 
Syarîf ini menduduki singgasana kerajaan melalui pewarisan atau melalui perebutan kekuasaan dikalangan anggota keluarganya. Kota-kota di Hijaz juga tetap dibawah keamîran Makkah. Seorang wakil terpercaya dari amîr duduk di setiap kota itu untuk menangani segala urusan politik. Di samping itu, amîr Makkah dan wakilwakilnya didampingi oleh pegawaipegawai asal Turki Utsmani. Orang-orang Turki Utsmani memberi kuasa kepada amîr untuk menjalankan kekuasaannya di sana.

Sultan Selim juga menetapkan pembagian pajak yang dihasilkan di Mesir. Sepertiga untuk Mesir, sepertiga dikirim ke Makkah dan Madinah, dan sepertiga lagi untuk dikirim ke Istanbul. $^{53}$ Dengan demikan, sebagai Khadim al- $\underline{\text { Haramayn }},{ }^{54}$ penguasa Utsmani itu telah menguasakan kepada pemerintah provinsi Mesir secara formal untuk mengelola dana bantuan dan subsidi guna melakukan dan mempertahankan tempat-tempat suci, institusi-institusi sosial kegamaan dan penduduk Makkah dan Madinah.

Menurut Azyumardi Azra, ada tiga macam bantuan yang dikirim pemerintah Utsmani di Mesir; pertama, uang kontan yang disebut Surre (dompet) yang dibagikan setiap tahun oleh Amîr al-Hajj kepada pegawai-pegawai rendah, ulama, dan penduduk Makkah dan Madinah, tercatat bahwa pada tahun 1533-1534 surre berjumlah 560 paras. Sekitar 10 persen surre, yang disimpan oleh pejabat-pejabat Kairo, kadangkala hanya 50 persennya saja

\footnotetext{
${ }^{53}$ Muhammad Farîd Bek al-Mahâmî, Târîkh al-Daulah al- 'Aliyyah al- 'Utsmaniyyah, Beirut: Dar al-Nafầ'is, 1406/1986), h. 195.

${ }^{54}$ Pernyataan sebagai pelindung (Khadim alHarâmayn) ini diikrarkan pada saat pelantikan Khayr Bey menjadi Gubernur Mesir, yaitu; "Saya berharap melihat saudara mengabdi Nabi (Muhammad) dengan baik. Saya tidak punya keinginan apapun dari Mesir. Saya hanya memiliki gelar "Pelayan Tanah Suci" dan saya telah melimpahkan seluruh pendapatan Mesir sebagai waqf kepada Yang Mulia Nabi. Bersaksilah bahwa sejak sekarang saudara menjadi penyalur waqf dan Tuhan. Jadi tunaikanlah dengan baik." Azyumardi Azra, Jaringan Ulama Timur Tengah, h. 65.
}

yang sampai kepada yang berhak menerimanya, namun jika kita melihat Surre yang dikeluarkan oleh Turki Utsmani sejak tahun 1527-1528, setiap tahunnya mengeluarkan kurang lebih sebesar 4,286,475 acke. ${ }^{55}$ Untuk lebih jelasnya bisa terlihat bagan berikut, untuk melihat jumlah pengeluaran yang dikeluarkan oleh Turki Utsmani untuk Hijaz.

\section{Tabel 3.1}

Tabel pengeluaran untuk Hijaz

Expenditure for Pilgrims and the Holy Cities from the Central Administration's Budget $^{56}$

\begin{tabular}{|l|l|l|l|}
\hline Year & $\begin{array}{l}\text { Ezpenditures } \\
\text { In Acke }(a)\end{array}$ & $\begin{array}{l}\text { Total } \\
\text { Budget } \\
(b)\end{array}$ & $\begin{array}{l}a / b \\
\text { as } \\
\%\end{array}$ \\
\hline $\begin{array}{l}1527- \\
8\end{array}$ & 4.286 .475 & 403.388 .322 & $\begin{array}{l}1.1- \\
1.2\end{array}$ \\
\hline 1653 & 7.142 .298 & 676.106 .387 & 1.1 \\
\hline $\begin{array}{l}1660- \\
1\end{array}$ & 10.898 .778 & 593.604 .361 & 1.8 \\
\hline $\begin{array}{l}1690- \\
1\end{array}$ & 16.567 .320 & 812.838 .365 & 2 \\
\hline
\end{tabular}

Kedua, Ta'yinat-i Eshraf-i Harameyn, yakni bantuan keuangan tahunan untuk pembelian bahan makanan dan keuangan tahunan untuk syarîf Makkah dan wakilnya di Madinah, keturunan Nabi, pemukapemuka dan ulama. Ketiga, yang merupakan kelanjutan dari tradisi Mamluk sebelumnya, yaitu menutupi biaya pembelian gandum dan bahan makanan

\footnotetext{
${ }^{55}$ Suraiya Faroqhi, Pilgrims and Sultans, h. 78 yang dikutip oleh Reyhan Biadillah, Kebijakan Ekonomi Turki Utsmani, (1514-1574 M), h. 72.

${ }^{56}$ Acke merupakan mata uang Turki Utsmani, dalam bahasa Arab disebut sebagai 'aqjah' yang berbahan dasar perak, yang setara dengan dinar Emas 1:45-50 (I kurs koin emas sultani, eshfriye, asper atau dinar sama dengan 45-50 Acke). Suraiya Faroqhi, Pilgrims and Sultans, h. 78 dan h. 199. Jika melihat data tersebut, kita bisa menghitung jumlah pengeluaran yang di berikan Turki Utsmani untuk Hijaz maka jumlahnya sedikit.
} 
lainnya yang dikirim ke Makkah dan Madinah. ${ }^{57}$

Selain itu pula ada waqf $f^{58}$ yang didirikan di Mesir. Pada masa Selim I, seluruh pendapatan yang berasal dari provinsi Mesir dialokasikan untuk kepentingan pembangunan Makkah dan Madinah. Hal ini diperjelas dengan pidatonya Selim I saat melantik Khayr Bey yang diangkat menjadi Gubernur Provinsi Mesir pada 1517. Bahwa pada 1567 tercatat 10.000 koin emas dan 10.000 irdeb gandum yang ternyata digelapkan oleh administrator lembaga itu. ${ }^{59}$

Sistem pemerintahan Turki Utsmani di Hijaz ini memberi kesempatan kepada para syarîf itu untuk merasakan adanya kemerdekaan terbatas dari intervensi langsung para penguasa politik yang berkedudukan di Istanbul. Namun, mereka sangat terkait kepada kekuatan di Mesir, karena mereka sangat bergantung kepada Mesir dalam persoalan (nafkah) kehidupan, karena Hijaz adalah negeri yang tidak banyak memiliki sumber penghasilan ekonomi. Diluar persoalan pendapatan itu, Hijaz tunduk kepada kebijakan politik Turki Utsmani, karena merekalah yang menentukan, menunjuk dan menghentikan amîr-amîr Makkah.

Akan tetapi, sultan mengambil kebijakan politik yang tidak menempatkan kekuasaan atas Hijaz kepada seorang individu saja, yaitu syarîf Makkah, tetapi kepada dua orang, sehingga tercipta dualisme politik di sana. Dalam hal ini, sultan menempatkan seorang pejabat Turki Utsmani pada jabatan al-Sançakiyyah yang yang berkedudukan di Jeddah. Dia diikuti oleh satu pasukan bala tentara lengkap,

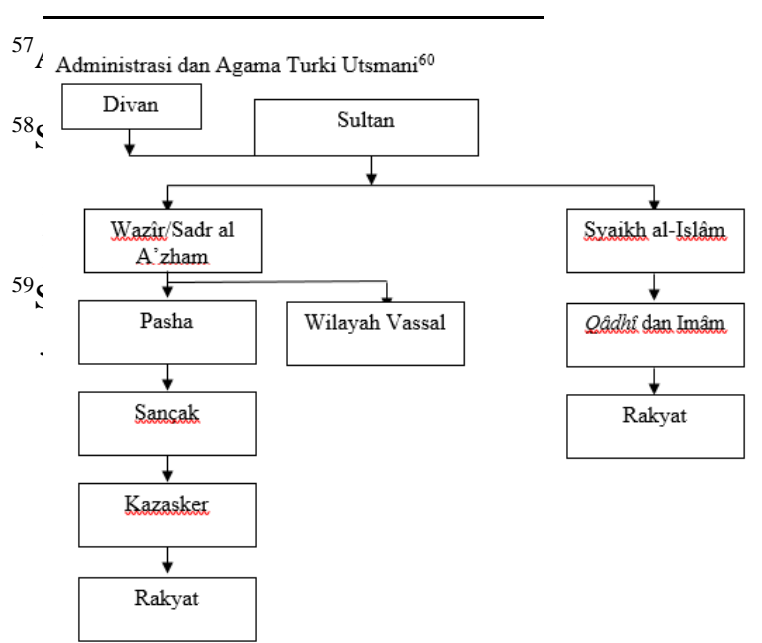

menggantikan posisi bala tentara Dinasti Mamluk sebelumnya.

\section{Tabel 3.2}

Stuktur pemerintahan

Dengan sistem pemerintahan seperti itu, di Hijaz pada umumnya terdapat dualisme kepemimpinan, Sançak yang berkedudukan di Jeddah dan syarîf Makkah. Sançak Jeddah mengenai persoalan-persoalan formal kenegaraan dan penduduk kota, sementara syarîf Makkah menjadi penguasa bagi kabilah-kabilah Arab Badui Hijaz. Sementara itu, di Madinah terdapat tiga pemimpin politik: Muhafidz yang merupakan perpanjangan tangan penguasa Turki Utsmani, Qaimaqam Syarîf yang merupakan perwakilan syarîf Makkah di Madinah, dan Amîr Madinah yang di duduki oleh keturunan Husain bin 'Ali.

Sistem pemerintahan Turki utsmani di Hijaz seperti ini ditetapkan pada masa pemerintahan Sultan Sulaiman al-Qânunî. Ketetapan resmi itu menentukan bahwa para syarîf berkedudukan di Makkah yang merupakan lembaga independen pemerintah, Sançak di Jeddah dan seorang Muhafidz di Madinah. Ditetapkannya jabatan ini bertujuan untuk mengatasi kecurangan dan sentralisasi pemerintahan politik di Hijaz tidak terpusat pada diri syarîf Makkah yang tetap dipertahankan oleh penguasa Turki Utsmani itu. Jabatan Sançak itu selalu ditempati oleh komandan angkatan bersenjata Turki Utsmani. ${ }^{60}$

Tabel 3.3

\section{Sistem Pemerintahan Hijaz masa Turki Utsmani. ${ }^{6}$}

\footnotetext{
${ }^{60}$ Suraiya Faroqhi, Pilgrims and Sultans, h. 33.

${ }^{61}$ Amîr (syarîf) Makkah mempunyai tentara khusus yang terdiri dari orang-orang Yaman dan sebagian orang-orang Badui asal pinggiran Makkah dan sebagian lagi dari negeri-negeri tetangga seperti Afrika Utara (Maghrib), Hadramaut dan Afganistan. Jumlahnya mencapai beberapa ribu orang tidak termasuk budak yang jumlahnya tidak lebih dari seribu.
} 


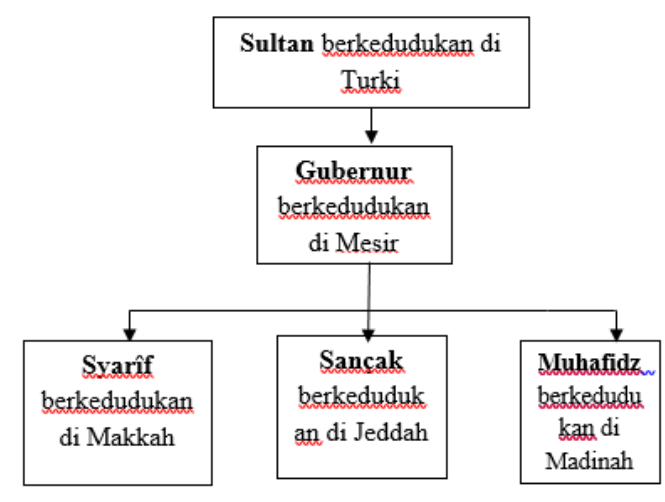

Ketika sistem pemerintahan ini dijalankan, Sançak Jeddah sangat menentukan dalam perjalanan politik di Hijaz. Hal ini terjadi karena para pejabat Turki Utsmani yang berkedudukan di Jeddah itu mendapat perintah langsung dari sultan Istanbul atau dari Gubernur Turki Utsmani yang berkedudukan di Mesir. Bahkan, pejabat Turki Utsmani yang berkedudukan di Jeddah ini sering juga terlibat langsung dalam memecat syarîf Makkah, menunjuk penggantinya dan mengukuhkannya, serta menghadiri upacara pengukuhannya. Sebagaimana Gubernur Turki di Mesir, Sançak juga mempunyai hak untuk mengadakan ekspansi dalam kedudukannya sebagai penguasa militer Hijaz, hal itu karena penguasa-penguasa Turki Utsmani mempercayainya dan bersandar pada pendapat-pendapatnya, arena merekalah yang paling dekat dengan masalah-masalah Hijaz. Istanbul sangat bersandar kepada pendapat Sançak Jeddah didalam pemilihan para syarîf.

Dalam perjalanan sejarahnya, kekuasaan pejabat Turki Utsmani yang berkedudukan di Jeddah itu menjadi semakin besar. Tampaknya usaha Turki Utsmani dalam memperkuat kekuasaannya di Hijaz ini, sejalan dengan proses kemundurannya sendiri. Para Sançak Jeddah itu mengambil keputusan politik yang berkenaan dengan persoalanpersoalan negeri Makkah dengan mengambil hak-hak politik dalam persoalan kesyaikhan Masjidil Haram di Makkah dan Masjid Nabawi di Madinah dan menjadikannya sebagai bagian dari kekuasaannya.

\section{Corak Keagamaan dan Aliran Pemikiran}

Menurut Badri Yatim perubahan corak pemikiran keislaman di suatu negeri Muslim sangat terkait erat dengan perubahan politiknya. Namun tidak dipungkiri perubahan itupun boleh jadi dipengaruhi oleh faktor lain seperti lingkungan dan perubahan sosialekonomi. $^{62}$ Selain itu pula, perubahan aliran pemikiran pun tergantung dari pemerintahan yang menguasai negeri itu. Siapa yang mampu menaklukkan negeri itu secara otomatis ia berkuasa untuk mengganti dan menanamkan faham alirannya.

Berawal dari penguasaan Dinasti Mamluk yang bercokol di Mesir dengan mengusung ortodoksi Sunni, ${ }^{63}$ Hijaz pun mulai diterapkan paham mengenai Sunni terlihat dari keseriusan Dinasti Mamluk yang mengirim seorang ulama bermadzhab Sunni dalam rombongan haji Mesir yang bertindak sebagai khatib dan imam. ${ }^{64}$ Setelah Dinasti Mamluk mulai bercokol di Mesir dan memperkokoh kedudukan aliran Sunni di Hijaz ia mulai menempatkan

${ }^{62}$ Badri Yatim, Perubahan Sosial Politik di Hijaz, h. 72.

${ }^{63}$ Paham Sunni yang di anut oleh Dinasti Mamluk tidak hanya menetapkan satu madzhab saja, namun memberlakukan juga keempat madzhab fikih Sunni, Syafi'i, Hanafi, Maliki dan Hambali. Berbeda dengan pemerintahan sebelumnya meskipun masih dalam satu paham Sunni namun hanya menetapkan satu madzhab saja yaitu madzhab Syaf'i.

${ }^{64}$ Di awal abad ke VIII H/XIV M, Dinasti Mamluk mulai menerapkan paham Sunni dengan memberikan jabatan seorang imam atau khatib atau $q \hat{a} d h \hat{\imath}$ setiap pergantian musim haji. Yang pertama kali diberikan jabatan menjadi imam dan khatib adalah Al-Siraj 'Umar ibn Ahmad Ibn al-khudâri alAnshâri al-Damanhuri al-Syafi'i, mempunyai paham aliran Sunni. Pemberian jabatan ini mulai dilakukan pada masa pemerintahan Sultan AlMansur al-Qallâwŭn tahun 682 H/1283 M. 
jabatan qâdhî di Masjidil Haram المسجد) (الحرم dan Masjid Nabawi (المسجد النبوي), bahkan seluruh petugas-petugas kebersihan yang berada di Hijaz diganti.

Sultan Mamluk mempunyai aturan tersendiri dalam mengangkat jabatan qâdhî, bukan berarti dia berkehendak semaunya, biasanya dengan mengeluarkan keputusan resmi untuk para qâdhî, pasalnya jabatan qâhdî ini dinilai sebagai jabatan terpenting kedua setelah jabatan Vilayet (politik) di Makkah dan Madinah. Semua yang menduduki jabatan itu mendapat gaji tetap tahunan yang menurut Badri Yatim dananya dikirim dari Mesir dan Suriah, dan besarnya disesuaikan dengan berat tidaknya tanggung jawab jabatan yang bersangkutan. ${ }^{65}$

Setelah Hijaz menjadi wilayah kekuasaan Turki Utsmani yang ditandai dengan berhasilnya Selim I menguasai Mesir tahun 1517 M, secara otomatis faham aliran ini pun berubah. Namun jika diamati dari beberapa periode sebelumnya kehadiran Turki Utsmani dalam panggung perpolitikan, terutama mengenai paham aliran, nampaknya perubahan ini tidak begitu signifikan dikarenakan Turki Utsmani pun mengusung aliran Sunni. Hanya ada sedikit perbedaan mengenai madzhab yang di ambil. Yang sebelumnya di berlakukan empat madzhab hukum fikih, sekarang menjadi satu madzhab saja yaitu madzhab Hanafi, maka dari itu di Makkah hanya ada satu yang bertindak sebagai $q \hat{a} d h \hat{\imath}$. Para penguasa Turki Utsmani pun bertindak tidak jauh berbeda dengan Dinasti Mamluk, ia berusaha memasukan madzhab Hanafi kedalam lembaga-lembaga formal pemerintahan. Namun jika dalam praktek lapangannya terdapat ketidakadilan dalam sistem pemerintahan maka penduduk Hijaz diperbolehkan untuk melapor dan meminta fatwa yang berkenaan dengan masalah yang dihadapi kepada tokoh penganut madzhabnya masing-masing.

\footnotetext{
${ }^{65}$ Badri Yatim, Perubahan Sosial Politik di Hijaz.
}

Untuk keagamaan sendiri, sejak perpindahan kekuasaan Turki ke Hijaz, peran sufisme cukup mencuat, mereka semakin disegani oleh kalangan elit militer dikarenakan mereka mampu menjelaskan bagaimana peranannnya dalam tradisi di Mesir. Menurut Syafiq A. Mughni, bahwa selama periode Turki Utsmani bercokol di Mesir, gerakah sufi menjadi fenomena keagamaan yang penting, beberapa tarekat berkembang di sana, seperti Khalwâtiyyah, Syadzîliyyah, Qadîriyyah, Rifâ'iyah, Naqsabandiyyah dan organisasi dibawah kepemimpinan yang terpusat. Mereka memiliki peranan yang penting dalam membentuk wajah kehidupan keagamaan yang baru dalam masyarakat Mesir. ${ }^{66}$

Perkembangan sufisme ini terlihat pada pendirian madrasah dan tradisi Sunni seperti peringatan Maulid dimana ribuan masyarakat dilibatkan didalamnya. Kemudian tradisi Ziyarah kebeberapa makam para wali menjadi bagian dari rutinitas kehidupan. Namun keberadaan sufisme ini kadangkala menimbulkan reaksi kegamaan. Di Makkah dan Madinah sendiri pengaruh tarekat sufi (sufisme) semakin tersebar luas. Sepanjang periode ini, tokoh ulama dan sufi memainkan peranan sosial dan politik yang penting, mereka menjadi penengah antara elit Mesir dan warganya.

\section{Lembaga Pendidikan dan Ilmu Keislaman}

Menurut Badri Yatim, bahwa persoalan menyangkut pendidikan di Hijaz, lebih dititikberatkan pada perkembangan sosialekonomi. Dikarenakan lembaga pendidikan ini bersifat taktis. Namun tidak menutup kemungkinan perkembangan lembaga pendidikan ini kadangkala dipengaruhi pula oleh perubahan suasana politik di Hijaz sendiri. ${ }^{67}$ Sebelum penguasaan Turki Utsmani di Hijaz, lembaga pendidikan dan pengajaran belum mengalami kemajuan. Terlihat di Madinah lebih dari tiga puluh

\footnotetext{
${ }^{66}$ Mughni, Sejarah Kebudayaan Islam di Turki, h. 77.

${ }^{67}$ Badri Yatim, Perubahan Sosial Politik di Hijaz, h. 62.
} 
tahun tidak terjadi perubahan dalam lembaga pendidikan. Ada beberapa faktor yang menjadi penentu kemajuan lembaga pendidikan tersebut diantaranya; kondisi perekonomian, adanya sikap perhatian penguasa terhadap pendidikan dan adanya waqf ke Tanah Suci.

Sulaiman I membangun lembaga pendidikan di Hijaz, yaitu sekitar empat sekolah, dan merupakan sekolah terbanyak sejak pemerintahan Abbasiyah. Sebenarnya jumlah pendidikan yang dibangun Turki Utsmani berjumlah lima buah, namun yang satu dibangun oleh Sultan Murad (9281300/1517-1594). ${ }^{68}$ Untuk pembangunan Masjidil Haram sendiri, dilakukan oleh Turki Utsmani pada masa Sulaiman alQânŭni dengan membangun secara menyeluruh, proyek pembangunan ini dilakukan pada tahun $980 \mathrm{H} / 1572 \mathrm{M}$ dan selesai pada pemerintahan anaknya yang bernama Murad II pada tahun 984H/1576 M. ${ }^{69}$

Disamping itu pula, masjid di Harâmayn kurang mendapatkan perhatian, dikarenakan hampir sepenuhnya tergantung kapada waqf, yang kebanyakan diberikan penguasa dan dermawan non-Hijazi. Kadangkala madrasah terlantar dikarenakan kurangnya bantuan waqf serta tidak adanya lembaga pengawasan. Sejak pemerintahan Turki Utsmani waqf di Harâmayn dikelola oleh lembaga yang bernama harameynvakiflari (pengelola waqf Harâmayn) meski terdapat lembaga tersebut, kasus penyimpangan dan salah urus menjadi hal yang sangat umum. ${ }^{70}$ Akibat penyimpangan ini konsekuensinya madrasah ditutup, disamping adanya madrasah itu, kebanyakan ulama Harâmayn lebih senang di masjid Al-Haram dan Al-

\footnotetext{
${ }^{68}$ Azyumardi Azra, Jaringn Ulama Timur Tengah, h. 57.

${ }^{69}$ Muhammad Ilyas Abdul Ghani, Sejarah Kota Mekah Klasik dan Modern, penerj. Samson Rahman, (Jakarta: Akbar Media Eka Sarana, 2003), Cet. I, h. 116.

${ }^{70}$ Azyumardi Azra, Jaringn Ulama Timur Tengah, h. 57.
}

Masjid Al-Nabawi dalam melakukan kegiatan pengajarannya dari pada di Madrasah yang dibangun.

Sejalan dengan proses pengajaran itu, pendidikan di Harâmayn sendiri di biayai dari kas negara, dengan jumlah yang semakin meningkat sampai mencapai 50.000 keping emas pertahun pada $1568 .^{71}$ Kemudian disebutkan bahwa tahun 1564-5 dan 1567-70, Masjidil Haram di beri wewangian yang menghabiskan biaya sekitar 250-500 keping emas. Anggaran perawatan Masjidil Haram pada tahun 1517, bertambah sekitar 40.000-50.000 keping emas, bahkan menambahkan perbaikan kubah-kubah Masjidil Haram sebanyak 400-500, dengan anggaran 100.000 keping emas meskipun pada ralisasinya hanya sebanyak 160 -an kubah. ${ }^{72}$

Kemudian Turki Utsmani memperbaiki gembok kunci Ka'bah, yang semula di buat oleh Sultan Abdul Hamid, Sultan khalifah Utsmani tahun 1309 H. Diperbaharui sesuai dengan ukuran gembok semula dengan pintu yang baru, hal ini dilakukan untuk pengamanan Ka'bah. ${ }^{73}$ Dan tidak lupa pula, Turki Utsmani berperan dalam tradisi pemberian Kiswah (كسوة) yang dahulunya tatkala pemerintahan Abbasiyah runtuh, Kiswah ini didatangkan dari Mesir atau Yaman. Setelah beberapa lama kemudian, Kiswah ini di datangkan dari Mesir masa pemerintahan Raja Salih Isma'il Qalun yang mewaqafkan tanah sebanyak tiga desa di pinggiran Kairo, Turki Utsmani menambahkan tujuh desa pada tahun $947 \mathrm{H}$ untuk tujuan pembuatan Kiswah. Sehingga tradisi pemberian Kiswah ini tetap dilakukan sepanjang musim haji. ${ }^{74}$

\footnotetext{
${ }^{71}$ Suraiya Faroqhi, Pilgrims and Sultants, h. 97.

${ }^{72}$ Biaya yang dianggarkan oleh Istanbul, berjumlah 53.782.980 akce (sebutan bagi satuan mata uang perak Turki Utsmani di Balkan dan Anatolia. Sebutan di Irak: shahis, di Hijaz dan Mesir. Ibid., h. 97 dan h. 102

${ }^{73}$ Muhammad Ilyas Abdul Ghani, Sejarah Kota Mekah Klasik dan Modern. (Jakarta: Akbar Media Eka Sarana, 2003), h. 70.

${ }^{74}$ Abdul Ghani, Sejarah Kota Mekah Klasik dan Modern, h.71. Bisa juga di lihat di link web berikut:
} 
Selain Kiswah, Selim dan Sulaiman I pun memerintah untuk membangun sumursumur dan pembangunan pipa air di Masjidil Haram ke Arafah tahun 1564-5 guna keperluan para kafilah haji dan dagang dalam perjalanan menuju Makkah dan Madinah, pembangunan ini dilakukan disepanjang daerah Hijaz yang tandus dan sepanjang jaringan perdagangan didalam wilayahnya, yang kemudian diteruskan pada April 1517 dengan biaya 3000 keping emas pada tahap pertama, pada tahap penyelesaiannya menghabiskan biaya sekitar 60.000 keping emas. $^{75}$ Dan perdana menteri Mohamed Sokolluu juga memerintahkan untuk membangun pemandian umum kepada qâdhî kota Makkah pada tahun 1567. Untuk pembangunan sistem air ini, bantuan Turki Utsmani cukup besar ketimbang dana dari penduduk lokal, namun terlepas dari semua itu, hal ini dilakukan demi kepentingan Makkah dan Madinah. ${ }^{76}$

\section{PENUTUP}

Hijaz sebagai simbolis keagamaan Islam, yang dinyatakan sebagai basis politik, rohani, spiritual dan intelektual. Selama rentang sebelum 1512-1566 M, baik dari segi pemerintahan, pendidikan dan tradisi keagamaan, kondisinya tidak stabil dan tidak begitu kuat pengaruhnya di Timur Tengah, dikarenakan Hijaz selalu terombang-ambing sesuai dengan pemerintahan yang berkuasa di Mesir. Berawal dari masa Khulafa' Al-Rasyidun yang dijadikan sebagai pusat keagamaan, kemudian jatuh dalam penguasaan bani

http://www.republika.co.id/berita/jurnalhaji/wijhat/1 3/09/09/msuji9-kisah-Selimut-kabah Akses: Senin, 17 Februari 2014, pukul 17.05 WIB.

${ }^{75}$ Suraiya Faroqhi, Pilgrims and Sultants, h. 98 dan dikutip oleh Reyhan Biadillah, Kebijakan Ekonomi Turki Utsmani, h. 69.

${ }^{76}$ William L. Ochsenwald, Ottoman Subsidies to the Hijaz 1877-1886, Vol. 6 No. 3 (Cambridge: University Press, 1975), h. 300-307 URL:http://www.jstor.org/stable/162109 Accessed: 05/03/2009 time: $02.47 \mathrm{pm}$.
Umayyah menjadi pusat intelektual, diteruskan oleh dinasti Fatimiyah yang malang melintang di Mesir dan Afrika Utara menjadikan Hijaz basis Syi'i, lanjut jatuh ke Dinasti Ayyubiyah berubah menjadi basis Sunni yang kemudian kontrol politik Hijaz diteruskan di bawah kekuasaan Dinasti Mamluk di Mesir, dan pada akhirnya penguasaan utuh pun ditangan Turki Utsmani.

Penguasaan Turki Utsmani atas Mesir menjadikan pemerintahan yang berkuasa di Timur Tengah, ditambah posisinya sebagai pelindung Umat Islam (khalifah) yang bernuansa Sunni, menjadikan kontrol politik Hijaz berada pada penguasaan Turki Utsmani dengan menetapkan Syarif sebagai pengganti pemerintah. Hijaz mulai dirilis kembali dengan menetapkan syarif di Hijaz. Kehadiran Turki Utsmani memberikan pengaruh yang besar dimana Hijaz sebagai pusat Spiritual dan intelektual mampu dibangkitkan kembali.

Kebijakan Turki Utsmani di Hijaz dalam rangka untuk menyelamatkan dunia Islam secara umum dan wilayah-wilayah Muslim secara khusus. Kemudian ditambah dalam rangka pengukuhannya di Timur Tengah, Turki Utsmani mengeluarkan kebijakan untuk menjaga stabilitas negaranya, diantaranya; di Mesir dengan menempatkan Syarif untuk mengelola pajak yang di distribusikan ke Mesir, Istanbul, Makkah-Madinah, yang masing-masing ditetapkan sejumlah sepertiga. Penguasaannya atas Mesir, Turki Utsmani berkewajiban menjaga Hijaz dengan mengeluarkan kebijakan berupa pengamanan jalur haji atas Portugis yang sedang beroperasi di Lautan Hindia, melindungi tanah Suci Makkah-Madinah.

Dengan dikeluarkannya kebijakan Turki Utsmani 1512-1566 M, memberikan dampak semakin menguat penguasaannya di Timur Tengah. Hal ini memberikan warna tersendiri di Timur Tengah. Dampak tersebut membawa kemajuan bagi Turki Utsmani di segala bidang, politik, ekonomi, sosial-budaya. Selain itu pula pengakuannya 
atas pelindung Islam (khalifah) membawa pengaruh yang signifikan terhadap politik, dimana semua negeri-negeri Islam mengakui atas kebesarannya, dan meminta gelar sultan kepadanya melalui Syarif Makkah. Hal ini merupakan pencapaian yang luar biasa. Hubungan diplomatik pun dijalin sedemikian rupa sehingga negerinegeri muslim berada dalam penguasaannya dengan berlandaskan madzhab Sunni. Tradisi intelektual di Makkah dan Madinah semakin menjamur. Pencapaian tersebut dilirik sebagai dampak dari kebijakan yang dikelurkan oleh Turki Utsmani selama penguasaanya $1512-1566 \mathrm{M}$.

\section{DAFTAR PUSTAKA}

\section{Buku:}

Abdul Ghani, Muhammad Ilyas. Sejarah Kota Mekah Klasik dan Modern. Jakarta: Akbar Media Eka Sarana, 2003.

Abdullah, Yusri Abdul Ghani. Historiografi Islam: dari Klasik Hingga Modern, judul asli; Mu'jam alMuarrikhin al-Muslimin:hats AlQur'an al-Tsani 'Asyr al-Hijri. Jakarta: PT Raja Grafindo Persada, 2004.

Abdurahman, Dudung. Metodologi Penelitian Sejarah. Yogyakarta: Ar Ruzz Media.

Allen Jr, Calvin H. Oman The Modernization Of The Sultanate, Colorado: West Viewer Press, 1987.

Amstrong, Karen. Islam Sejarah Singgkat, terj. Fungky K.T. Yogyakarta: Penerbit Jendela, 2005.

Armağan, Mustafa. Osmanlı Ansiklpedisi Tarih Medeniyet Kultur, Istanbul: Íz yayıncılık, 1996.
Ash-Shalabi, Ali Muhammad. Bangkit \& Runtuhnya Khalifah Utsmaniyah, terj. Samson Rahman. Jakarta: Pustaka Al-Kautsar, 2002.

Azra, Azyumardi. Jaringan Ulama Timur Tengah dan Kepulauan Nusantara abad XVII dan XVII akar pembaharuan Islam di Indonesia. Jakarta: Prenada Media, 2004.

Biadillah, Reyhan. Kebijakan Ekonomi Turki Utsmani 1514-1574 M. Skripsi S1 Fakultas Adab dan Ilmu Budaya, Universitas Islam Negeri Sunan Kalijaga Yogyakarta, 2010.

D. J. M. Tate, The Making of Modern South East Asia Vol. 1 The European Conquest, Kuala Lumpur: Oxford University Press, 1971.

Esposito, Jhon L. Ensiklopedi Dunia Islam Modern, Jilid I, Bandung: Mizan, 2001.

Eversley's, Lord. The Turkish Empire, Lahore: Syaikh Muhammad Ashraf Kashmiri Bazar, 1954.

Farid bek al-Mahami, Muhammad. Tarikh al-Daulah al-Aliyyah alUtsmaniyyah. Beirut: Dar AlNafa'is, 1406/1986.

Faroqhi, Suraiya. Pilgrims and Sultants, The Hajj Under The Ottoman 1517-1683. London: I.B. Tauris \& Co.Lt, 1994.

Freely, John. Istanbul Kota Kekaisaran. penerj. Fahmy Yamani. Jakarta: Pustaka Alfabet, 2012.

Gottschalk, Louis. Mengerti Sejarah. Terj: Nugroho Notosusanto. Jakarta: UI Press, 1983. 
Hassan, Ibrahim Hassan, Sejarah dan Kebudayaan Islam, Yogyakarta: Kota Kembang, 1968.

Heritage, Andrew. The Time Atlas of Word History. London: Time Books Limited, 1984.

Hitti, Philip K. History of the Arabs, edisi revisi dari History of the Arabs; From the Earliest Times to the Present, ed. 10, Penerj. R. Cecep Lukman dan Dedi Slamet Riyadi. New York: Palgrave Macmillan Press, 2002.

Hurgronje, Christiaan Snouck. Perayaan Makkah. Jakarta: INIS Indonesian Netherlands Cooperation in Islamic Studies, 1889.

Inalcık, Halıl. The Ottoman Empire the Classical age 1300-1600, London: A Phoenix paperback, 1994.

Journal of Middle East Studies, Vol. 6, No. 3 (Jul., 1975), pp. 300-307 Published by: Cambridge University Press Stable URL: http://www.jstor.org/stable/1621 $\underline{09}$

Jr. Arthur, Goldschmidt. Concist History of The Middle East, The American University in Cairo Press, 1979.

Kartodirjo, Sartono. Pendekatan Ilmu Sosial dan Metodologi Sejarah. Jakarta: PT Gramedia Pustaka Utama, 1992.

Khaldun, Ibn. Muqaddimah, terj. Ahmadie Thoha, Jakarta: Pustaka Firdaus, 2001.

Marbun, B.N. (ed). Kamus Politik.. Jakarta: Pustaka Sinar Harapan, 2007.
Michael Llewellyn, Smith. The Fall of Constantinople, in History Makers magazine. London, Marshall Cavendish, Sidgwick \& Jackson, 1969.

Misbah, Ma'ruf. Sejarah Peradaban Islam untuk kelas Madrasah Aliyah III. Semarang: Wicaksana, 1986.

Mufrodi, Ali. Kerajaan Utsmani, Jakarta: PT Ichtiar baru van Hoeve, 2002

Mughni, Syafiq A. Sejarah Kebudayaan Islam di Kawasan Turki. Jakarta: Logos, 1997.

Nasution, Harun. Islam ditinjau Dari Berbagai Aspeknya jilid II. Jakarta: Universitas Indonesia, 1986.

Nata, Abuddin. Sejarah Pendidikan Islam Pada Periode Klasik dan Pertengahan. Jakarta: PT Raja Grafindo Persada, 2004.

Ochsenwald, William L. Ottoman Subsidies to the Hijaz, 1877-1886, International.

Parsons, Wayne. (ed). Public Policy: Pengantar Teori dan Praktik Analisis kebijakan. Jakarta: Kencana, 2008.

Putuhena, M. Saleh. Historiografi Haji. Yogyakarta: PT LKiS Pelangi Aksara Yogyakarta, 2007.

Rahman, Fazlur. Islam dan Modernitas Tentang Transformasi Intelektual. Yogyakarta: 1985.

Reid, Anthony. Dari Ekspansi Hingga Krisis Jilid II: Jaringan Perdagangan Global Asia Tenggara, ter. R. Z. Leirissa. 
Jakarta: Yayasan Obor Indonesia, 1999.

Saepudin, Didin. Sejarah Peradaban Islam. Jakarta: UIN Jakarta Press, 2007.

Shaw, Stanford J. History of the Ottoman Empire and Modern Turkey, Vol. I: Empire of the Gazis: The Rise and Decline of the Ottoman Empire, 1280-1808. Melbourne: Cambridge University Press, 1997.

Shihab, M. Quraish. Membaca Sirah Nabi Muhammad SAW Dalam Sorotan Al-Qur'an dan Hadits-hadits Shahih. Jakarta: Lentera Hati, 2011.

Sobari. "Kebijakan Pemerintah Sultan Sulaiman I (918-926/1512-1520 M." Skripsi S1 Fakultas Adab dan Budaya, Universitas Islam Negeri Sunan Kalijaga Yogyakarta, 2009.

Soenarjo, R.H.A. Al-Qur'an dan terjemahnya, Mujamma' AlMalik Fahd li Thiba'at AL-Mushhaf Asy-Syarif medinah Munawwarah. Kerajaan Saudi Arabia, 1971.

Sugono, Dendy. Kamus Bahasa Indonesia. Jakarta: Pusat Bahasa Departemen Pendidikan Nasional, 2008.

Sunanto, Musyrifah. Sejarah Islam Klasik perkembangan Ilmu pengentahuan Islam.

Syalabi, Muhammad. Sejarah dan kebudayaan Islam I. Jakarta: Al Husna Zikra, 1997.

Tim Penyusun, Pedoman Penulisan Karya Ilmiah Skripsi, Tesis, dan
Disertasi. Jakarta: UIN Jakarta Press, 2013/2014.

van Bruinessen, Martin. Kitab Kuning Pesantren dan Tarikat Tradisitradisi Islam di Indonesia. Bandung: Mizan, 1995.

Yatim, Badri. Perubahan Sosial Politik di Hijaz 1800 s/d 1925 dan Pengaruhnya terhadap lembaga dan kehidupan Keagamaan; Perspektif Sejarah Sosial, dalam bukunya Sejarah Sosial Keagamaan Tanah Suci; Makkah dan Madinah 1800-1925. Jakarta: Logos Wacana Ilmu, 1999.

Yayın, Çamlıca Basım. Muhtasar Osmanlı Târihi (1299-1922), Ed. III, Istanbul: Çamlıca Târih Kitapları Serisi 3, 2008.

Yunus, Mahmud. Sejarah Pendidikan Islam dari Zaman Nabi SAW Khalifahkhalifah Rasyidin, Bani Umayyanh dan Abbasiyah sampai Zaman Mamluk dan Utsmaniyah. Jakarta: PT Hidayakarya Agung, 1990.

Zainuddin, A. Rahman. Kekuasaan dan Negara: Pemikiran Politik Ibn Khaldun, Jakarta: Gramedia Pustaka Umat, 1992.

\section{Internet:}

http://www.britannica.com/EBchecked/topi c/360799/Mamluk. Akses: 5 Februari 2014 pukul: 17.15 WIB.

http://www.jurnalhaji.com/pernik-haji/hajipadamasadaulahutsmaniyah/\#sthash. WBD2N6at. dpuf. Akses 30 januari 2014, pukul: 09.28 WIB.

http://www.republika.co.id/berita/jurnalhaji/wijhat/13/09/09/msuji9- 
384 Al-Turāis Vol. XXI, No. 2, Juli 2015

kisah-selimut-kabah. $\quad$ Akses

Senin, 17 Februari 2014, pukul: 17.05 WIB.

http://www.turkislamtarihi.nl/makaleler/ace .php “Osmanli'dan Endonezya'nın Açe adasına yardım". Akses 17 September 2013, pukul: 14.35 WIB. 